\title{
Peripheral Developing Odontoma or Peripheral Ameloblastic Fibro-Odontoma Erupting to Oral Cavity Case Report
}

\author{
Odontoma en Desarrollo Periférico o Fibro-Odontoma Ameloblástico \\ Periférico Eruptando a Cavidad Oral Reporte de Caso \\ William Contreras ${ }^{1,2}$; Claudia Fernández ${ }^{1,3}$ \& Cesia de $\mathrm{Paz}^{2,4}$
}

CONTRERAS, W.; FERNÁNDEZ, C. \& DE PAZ, C. Peripheral developing odontoma or peripheral ameloblastic fibro-odontoma erupting to oral cavity. Case report. Int. J. Odontostomat., 12(2):117-120, 2018.

\begin{abstract}
The appearance of mixed odontogenic tumors into the oral cavity is a rare event. It is considered that some mixed tumors are only a stage in the complete development of a hamartomatous formation such as ameloblastic fibroodontoma and odontoma. Both pathologies share in common cellular elements which at one point makes them indistinguishable from each other. We present the case of a 21 year old patient who showed a mandibular growth whose histological elements present characteristics of both pathologies. The treatment was surgical excision of the lesion. There were no complications or recurrences to periodic reevaluation.
\end{abstract}

KEY WORDS: mixed odontogenic tumours, ameloblastic fibro-odontoma, complex odontoma, odontoma, developing odontoma.

INTRODUCTION

Odontogenic tumors are classified according to the embryonic origin of each pathology. Within the current classification there are mixed tumors, which contain odontogenic epithelium and ectomesenchyma resembling the dental papilla (Barnes et al., 2005). Odontoma is the most common of mixed odontogenic tumors, these can be classified into two types: Complex, which involves the formation of amorphous looking dental tissues grouped into masses; and compound, where the formations resemble rudimentary teeth separated from each other but grouped in the same follicular sac (Mikami et al., 2013). The ameloblastic fibro-odontoma is another benign tumor that has the combination of both tissue elements (epithelium and mesenchyme) and is able to form mineralized dental tissue, its appearance is not as frequent as odontoma and in most cases occurs in children (Kirjavainen et al., 2016). Both odontoma and ameloblastic fibro-odontoma share similar characteristics: presence of ectomesenchyma, islets or cords of odontogenic epithelium and the capacity to form dental mineralized tissue (Singh et al., 2016). The presence at peripheral tissues and the eruption into the oral cavity of both pathologies is an extremely rare event. The objective of the present study is to report the occurrence of a complex odontoma or ameloblastic fibro-odontoma erupting into the oral cavity in a 21 year-old patient.

Patient Information. 21 years old patient was referred to the clinic of the Dentistry Division of the Western Universitary Center by lesion located in alveolar mandibular ridge. At interrogation he did not mention any antecedent of importance, nevertheless the patient mentioned the "extraction" of what apparently were pieces of teeth in multiple occasions. Clinical intraoral exam showed an ovoid-shaped nodule, located in the alveolar ridge instead of eruption

\footnotetext{
${ }^{1}$ Dentistry Division, Western Universitary Center, San Carlos University of Guatemala, Quetzaltenango, Guatemala.

${ }^{2}$ Oral Diagnosis, Dentistry Faculty, Mesoamerican University, Quetzaltenango, Guatemala.

${ }^{3}$ Oral and Maxillofacial Surgery, Medical and Surgical Area, Dentistry Division, Western Universitary Center, San Carlos University of Guatemala, Quetzaltenango, Guatemala.

${ }^{4}$ Dr. Rodolfo Robles Hospital, Quetzaltenango, Guatemala.
} 
of 3.2, sessile base, firm consistency, similar color to the adjacent mucosa, lobular surface with the presence of amorphous masses of hard consistency resembling dental tissue, asymptomatic and 2 years of evolution. The patient was indicated for panoramic and intra-oral periapical radiographic study to determine the situation of piece 3.2 (Fig. 1A, 1B, 1C). Under this description a presumptive diagnosis of Complex Odontoma was made with 3.2 non-erupted. Excisional biopsy is indicated to confirm diagnosis.
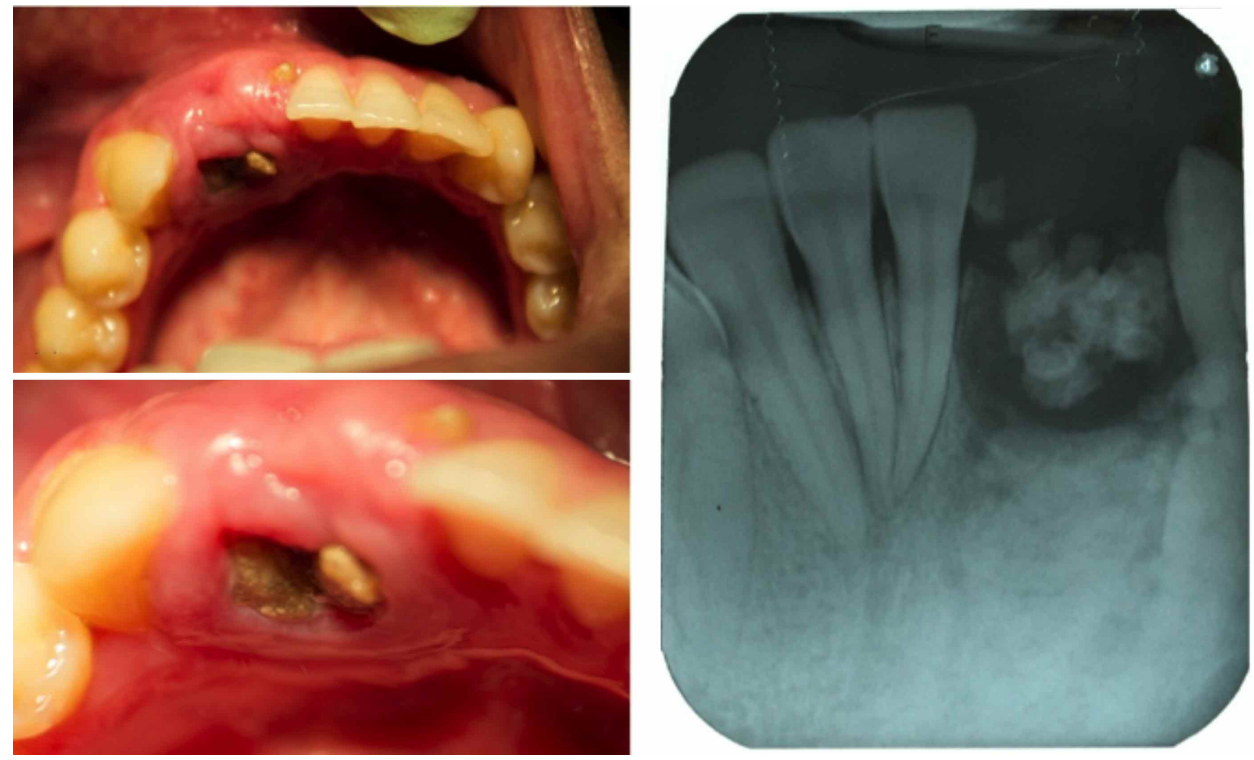

Fig. 1. Preoperative aspect of the lesion. A. Occlusal view, no presence of 3.2. B. Hard masses erupting to oral cavity. C. Radiographic aspect with presence of 3.2.
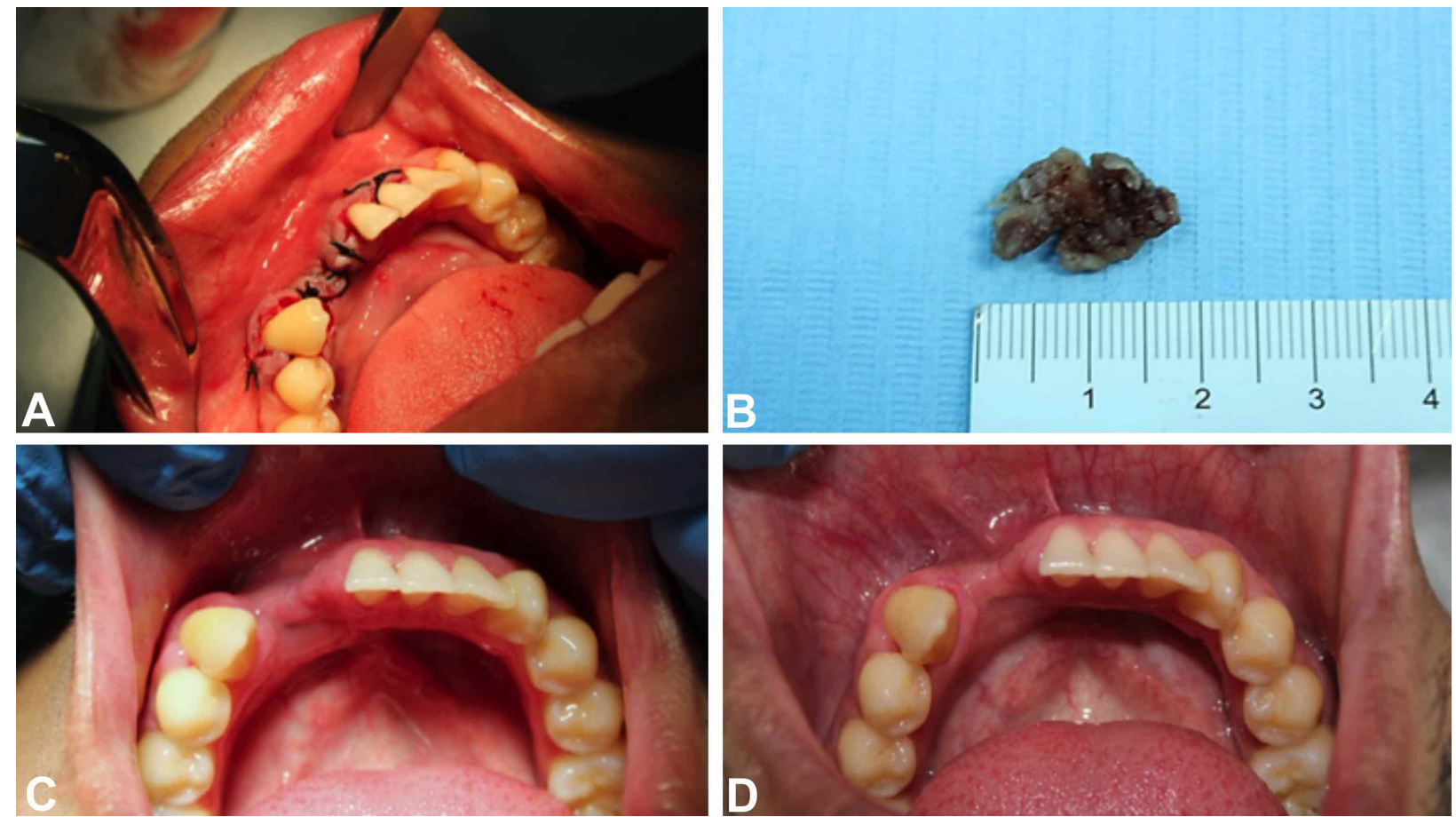

Fig. 2. A. Postoperative aspect of the surgical excision of the lesion. B. Excised specimen. C. 8 days reassessment. D. 1 month reassessment. 
remaining bone is examined, which shows normal appearance and consistency. The remaining tissue is removed and sutured with vicryl 3-0, without any complications. Postoperative indications are given and the patient was prescribed with broad spectrum antibiotics and non-steroid anti-inflammatory drugs (NSAIDs). The patient was reassessed clinically at 8 days and a month (Fig. 2A-D).

The histopathological study yielded the following findings: a large number of stellate fibroblasts with elongated nucleus were observed underlying normal stratified squamous epithelium. Immersed in this fibroblast proliferation the presence of islets and cords

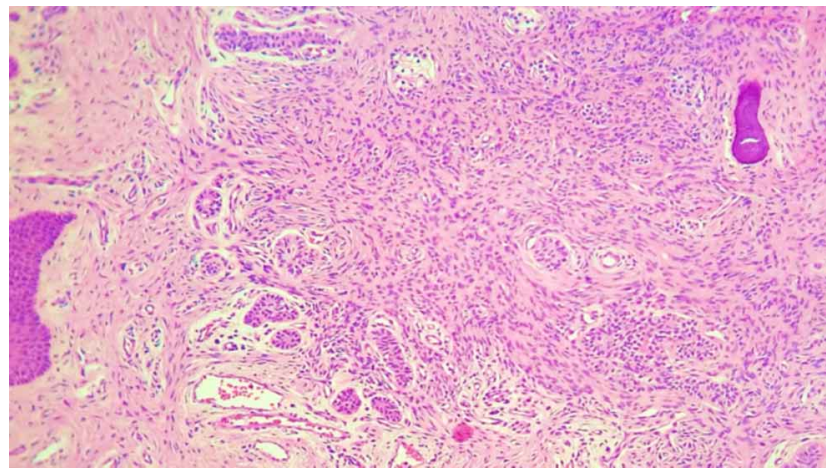

Fig. 3. Fibroblastic proliferation with islets of odontogenic epithelium and amorphous calcifications
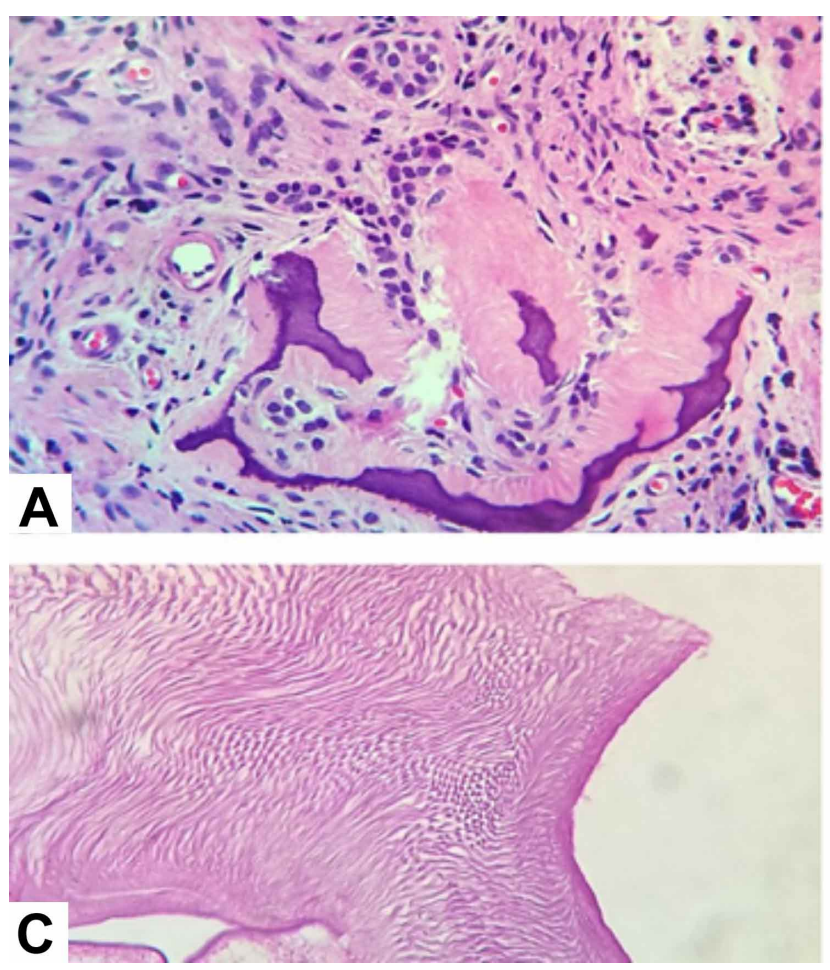

of odontogenic epithelium and amorphous calcifications was evident (Fig. 3, Figs. 4A-B). Likewise the hard portions of tissue show formation of dentinal tissue and enamel matrix (Figs. 4C-D). The definitive diagnosis was: Developing Odontoma or Ameloblastic Fibro-odontoma.

\section{DISCUSSION}

In the dental development process, epithelial tissues and ectomesenchyma are involved. From this interaction between both, the structure of the tooth arises as such (Barnes et al.). The epithelial rests that remain as part of the formation of the tooth may be the probable origin of pathologies such as odontoma or ameloblastic fibro-odontoma, which histologically present similarities that make them to some extent indistinguishable from each other, and may represent different stages in the formation of dental tissue (Silva et al., 2009). Both pathologies share histological features such as: Islets or cords of odontogenic epithelium surrounded by mesenchymal tissue that resembles the dental papilla, in addition to the presence of mineralized dental elements (dentin and enamel). Our case presented these characteristics typical of both pathologies, however it is practically impossible to

Fig. 4. A. Odontogenic epithelia adjacent to amorphous calcifications. B. Islets of odontogenic epithelium. C. Enamel matrix formed within the lesion. D. Dentin with characteristic tubules formed within the lesion. 
differentiate one pathology from the other in early stages of formation.

The origin of this pathology at molecular level is attributed to the alteration in the b-catenin pathway and to CD44 which have been shown to be actively involved in the development of other odontogenic tumors, such as ameloblastoma (Lin et al., 2014). At clinical / radiographic level, both pathologies may present as nodular growths of firm consistency, usually in gingival tissues and in relation to retained or non-erupted dental elements ( $80 \%$ of the cases present a non-erupted tooth) (Gedik \& Müftüoglu, 2014), which was manifested in our case.

The appearance of peripheral lesions of mixed origin is extremely rare, and even more so the eruption of their mineralized tissues. Authors have described the appearance of odontomas of complex type towards buccal cavity (Kaur et al., 2012), and peripheral ameloblastic fibromas (Reibel et al., 2011). However, some authors consider that the age of the patient is of importance and mention that from 22 years should be classified as a neoplasia not a hamartoma (Buchner \& Vered, 2013). Our case could be typecasted in the neoplastic aspect as the patient was 21 years old.

Conservative surgical excision is the recommended treatment for this type of pathology and recurrence is rare (Reibel et al.), this was the procedure performed in the case we presented.

\section{CONCLUSION}

Developing odontoma or Ameloblastic Fibroodontoma are considered as a same pathology at early stages of formation. Histologically both are indistinguishable from each other, as such they should be treated by conservative surgical excision. Our case presented these characteristics and was treated successfully with no recurrences or complications.

CONTRERAS, W.; FERNÁNDEZ, C. \& DE PAZ, C. Odontoma en desarrollo periférico o fibro-odontoma ameloblástico periférico eruptando a cavidad oral. Reporte de caso. Int. J. Odontostomat., 12(2):117-120, 2018.

RESUMEN: La aparición de tumores odontogénicos mixtos en la cavidad oral es un evento raro. Se considera que algunos tumores mixtos son solo una etapa en el desarrollo completo de una formación hamartomatosa como el fibro-odontoma ameloblástico y odontoma. Ambas patologías comparten ele- mentos celulares comunes que en un punto los hacen indistinguibles entre sí. Presentamos el caso de un paciente de 21 años que mostró un crecimiento mandibular cuyos elementos histológicos presentan características de ambas patologías. El tratamiento fue la escisión quirúrgica de la lesión. No hubo complicaciones o recurrencias a la reevaluación periódica.

PALABRAS CLAVE: tumores odontogénicos mixtos, fibro-odontoma ameloblástico, odontoma complejo, odontoma, odontoma en desarrollo.

\section{REFERENCES}

Barnes, L.; Eveson, J. W.; Reichart, P. \& Sidransky, D. World Health Organization Classification of Tumours, Pathology and Genetics of Head and Neck Tumours. Lyon, IARC Press, 2005.

Buchner, A. \& Vered, M. Ameloblastic fibroma: a stage in the development of a hamartomatous odontoma or a true neoplasm? Critical analysis of 162 previously reported cases plus 10 new cases. Oral Surg. Oral Med. Oral Pathol. Oral Radiol., 116(5):598-606, 2013.

Gedik, R. \& Müftüoglu, S. Compound odontoma: Differential diagnosis and review of the literature. West Indian Med. J., 63(7):793-5, 2014.

Kaur, G. A.; Sivapathasundharam, B.; Berkovitz, B. K. \& Radhakrishnan, R. A. An erupted odontoma associated with pigmentation: a histogenetic and histological perspective. Indian J. Dent. Res., 23(5):699, 2012

Kirjavainen, A.; Tuovinen, V. \& Sándor, G. K. Large ameloblastic fibroodontoma in a 7-year-old girl with analysis of 108 cases. Ann. Maxillofac. Surg., 6(1):15-20, 2016.

Lin, Y. C.; Hsu, H. M.; Liu, C. S. \& Yuan, K. A peripheral ameloblastic fibro-odontoma in a 3-year-old girl: Case report, immunohistochemical analysis, and literature review. Case Rep. Dent., 2014:321671, 2014.

Mikami, T.; Yagi, M.; Mizuki, H. \& Takeda, Y. Congenital peripheral developing odontoma accompanied by congenital teratomatous fibroma in a 9-month-old boy: a case report. J. Oral Sci., 55(1):8991, 2013.

Reibel, J.; Grønbaek, A. B. \& Poulsen, S. Peripheral ameloblastic fibroodontoma or peripheral developing complex odontoma: report of a case. Int. J. Paediatr. Dent., 21(6):468-70, 2011.

Silva, A. R.; Carlos-Bregni, R.; Vargas, P. A.; de Almeida, O. P. \& Lopes, M. A. Peripheral developing odontoma in newborn. Report of two cases and literature review. Med. Oral Patol. Oral Cir. Bucal, 14(11):e612-5, 2009.

Singh, A. K.; Kar, I. B.; Mishra, N. \& Sharma, P. Ameloblastic fibroodontoma or complex odontoma: Two faces of the same coin. Natl. J. Maxillofac. Surg., 7(1) :92-5, 2016.

Corresponding author:

Dr. William Contreras

Dentistry Division

Western Universitary Center

San Carlos University of Guatemala

Quetzaltenango, Guatemala

Calle Rodolfo Robles 29-99

Quetzaltenango

GUATEMALA

Received: $19-02-2018$

Accepted: 04-04-2018

E-mail: wicontreras@cunoc.edu.gt 